\title{
Chemical Preparation, Thermal Behavior and IR Studies of the New Chromium Diphosphate Hydrate and Crystal Structure of its Corresponding Anhydrous
}

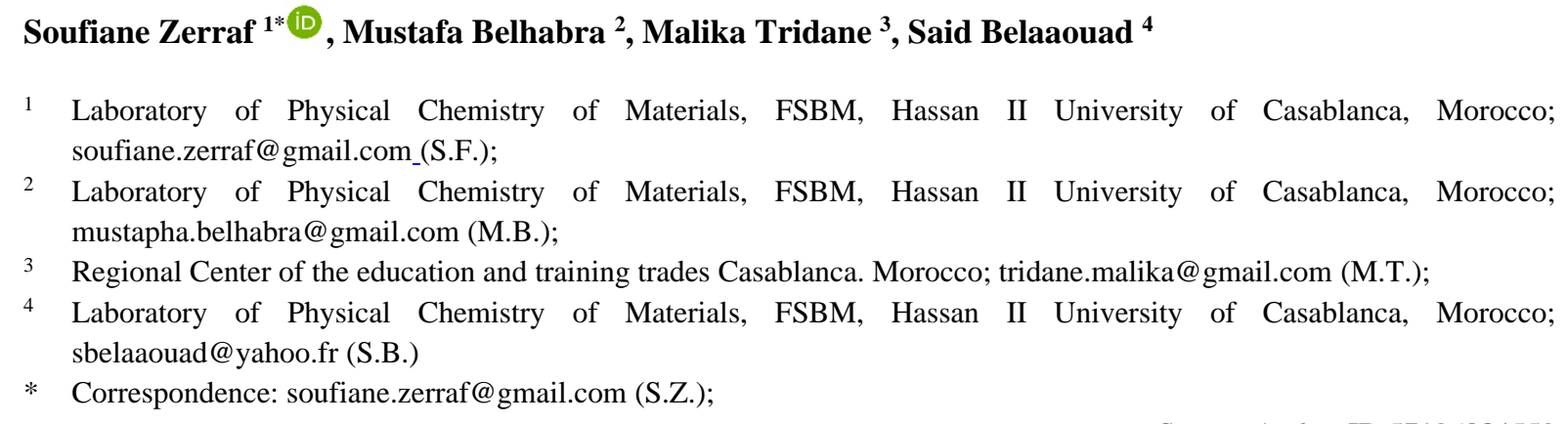

Received: 10.01.2021; Revised: 8.02.2021; Accepted: 10.02.2021; Published: 13.02.2021

Abstract: Chemical preparation, thermal behavior, and IR studies are given for the diphosphate $\mathrm{Cr}_{4}\left(\mathrm{P}_{2} \mathrm{O}_{7}\right)_{3} .28 \mathrm{H}_{2} \mathrm{O}$ and its anhydrous form $\mathrm{Cr}_{4}\left(\mathrm{P}_{2} \mathrm{O}_{7}\right)_{3} . \mathrm{Cr}_{4}\left(\mathrm{P}_{2} \mathrm{O}_{7}\right)_{3} \cdot 28 \mathrm{H}_{2} \mathrm{O}$, is monoclinic $\mathrm{P} 2 / \mathrm{m}$ with the following unit-cell dimensions : $\mathrm{a}=16.169(1) \AA, \mathrm{b}=9.336(5) \AA, \mathrm{c}=9.446(4) \AA, \beta=124.796(5)^{\circ}$, and $\mathrm{Z}$ $=4$. The total dehydration of $\mathrm{Cr}_{4}\left(\mathrm{P}_{2} \mathrm{O}_{7}\right)_{3} \cdot 28 \mathrm{H}_{2} \mathrm{O}$, between $90^{\circ} \mathrm{C}$ and $450^{\circ} \mathrm{C}$, leads to its anhydrous form, $\mathrm{Cr}_{4}\left(\mathrm{P}_{2} \mathrm{O}_{7}\right)_{3}$. $\mathrm{Cr}_{4}\left(\mathrm{P}_{2} \mathrm{O}_{7}\right)_{3}$ is isotopic to $\mathrm{V}_{4}\left(\mathrm{P}_{2} \mathrm{O}_{7}\right)_{3}$, crystallizing in the orthorhombic system, space group Pmcn, $\mathrm{Z}=4$ with the following unit-cell dimensions: $\mathrm{a}=7.25(2), \mathrm{b}=9.38(1) \AA$ and $\mathrm{c}=21.00(4) \AA$. $\mathrm{Cr}_{4}\left(\mathrm{P}_{2} \mathrm{O}_{7}\right)_{3}$ is stable until its melting point at $1050^{\circ} \mathrm{C}$. The thermal behavior of $\mathrm{Cr}_{4}\left(\mathrm{P}_{2} \mathrm{O}_{7}\right)_{3} .28 \mathrm{H}_{2} \mathrm{O}$ has been investigated and interpreted by comparison with IR absorption spectrometry and $\mathrm{X}$-ray diffraction experiments.

Keywords: chemical preparation; thermal behavior; infrared spectrometry; X-ray diffraction.

(C) 2021 by the authors. This article is an open-access article distributed under the terms and conditions of the Creative Commons Attribution (CC BY) license (https://creativecommons.org/licenses/by/4.0/).

\section{Introduction}

Today there is current interest in the chemistry of materials containing diphosphates. They are involved in bioenergetics [1-3] and catalytic processes [4]. The existence of acidic diphosphate anions, such as $\left(\mathrm{P}_{2} \mathrm{O}_{7}\right)^{4-},\left(\mathrm{HP}_{2} \mathrm{O}_{7}\right)^{3-},\left(\mathrm{H}_{2} \mathrm{P}_{2} \mathrm{O}_{7}\right)^{2-}$ and $\left(\mathrm{H}_{3} \mathrm{P}_{2} \mathrm{O}_{7}\right)^{-}$, has been well established for a long time [5]. Such anions, interconnected by strong hydrogen bonds, have geometric characteristics showing infinite networks of varied geometries ranging from chains to three-dimensional networks [6-10].

This paper describes the chemical preparation, thermal behavior, and vibration properties of the new diphosphates $\mathrm{Cr}_{4}\left(\mathrm{P}_{2} \mathrm{O}_{7}\right)_{3} .28 \mathrm{H}_{2} \mathrm{O}$. 


\section{Materials and Methods}

\subsection{Synthesis.}

2.1.1. Chemical preparation of $\mathrm{Cr}_{4}\left(\mathrm{P}_{2} \mathrm{O}_{7}\right)_{3} .28 \mathrm{H}_{2} \mathrm{O}$.

Polycrystalline Sample of the title compound, $\mathrm{Cr}_{4}\left(\mathrm{P}_{2} \mathrm{O}_{7}\right)_{3} .28 \mathrm{H}_{2} \mathrm{O}$ was prepared by slowly adding dilute diphosphoric acid to aqueous solutions of chrome carbonate according to the following chemical reaction:

$$
3 \mathrm{H}_{4} \mathrm{P}_{2} \mathrm{O}_{7}+4 \mathrm{Cr}_{2}\left(\mathrm{CO}_{3}\right)_{3}+22 \mathrm{H}_{2} \mathrm{O} \longrightarrow \mathrm{Cr}_{4}\left(\mathrm{P}_{2} \mathrm{O}_{7}\right)_{3} .28 \mathrm{H}_{2} \mathrm{O}+4 \mathrm{CO}_{2}
$$

The so-obtained solution was then slowly evaporated at room temperature until a polycrystalline sample of $\mathrm{Cr}_{4}\left(\mathrm{P}_{2} \mathrm{O}_{7}\right)_{3} \cdot 28 \mathrm{H}_{2} \mathrm{O}$ was obtained. The diphosphoric acid used in this reaction was prepared from an aqueous solution of $\mathrm{Na}_{4} \mathrm{P}_{2} \mathrm{O}_{7}$ passed through an ion-exchange resin, "Amberlite IR 120" [11].

2.1.2. Chimical preparation of $\mathrm{Cr}_{4}\left(\mathrm{P}_{2} \mathrm{O}_{7}\right)_{3}$.

$$
2 \mathrm{Cr}_{2} \mathrm{O}_{3}(\mathrm{~s})+6\left(\mathrm{NH}_{4}\right)_{2} \mathrm{HPO}_{4}(\mathrm{~s}) \stackrel{850^{\circ} \mathrm{C} / 48 \mathrm{~h}}{\longrightarrow} \mathrm{Cr}_{4}\left(\mathrm{P}_{2} \mathrm{O}_{7}\right)_{3}(\mathrm{~s})+12 \mathrm{NH}_{3}(\mathrm{~g})+9 \mathrm{H}_{2} \mathrm{O}(\mathrm{g})
$$

Powder diffraction patterns for the title compound were collected with a Diffractometer

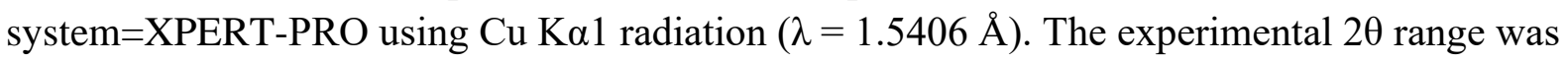
from 5 to $70^{\circ} 2 \theta$ with a step size of $0.01^{\circ}$ and a counting time of $15 \mathrm{~s}$ per step.

\subsubsection{IR absorption studies.}

Spectra were recorded in the range 4000-400 cm-1 with a "Bio-Red FTS 6000" spectrometer, using samples dispersed in spectroscopically pure $\mathrm{KBr}$ pellets.

\subsubsection{Thermal analysis.}

TGA-DTA coupled were performed using the SETARAM model TG-DTA 92 (GMIIPCMS) operating from room temperature up to $600^{\circ} \mathrm{C}$, in a platinum crucible and atmospheric pressure with sample mass: $7.25 \mathrm{mg}$, at a heating rate $10^{\circ} \mathrm{C} / \mathrm{min}$.

\section{Results and Discussion}

\subsection{Crystallographic characterization.}

3.1.1. Crystallographic data of $\mathrm{Cr}_{4}\left(\mathrm{P}_{2} \mathrm{O}_{7}\right)_{3} .28 \mathrm{H}_{2} \mathrm{O}$.

$\mathrm{Cr}_{4}\left(\mathrm{P}_{2} \mathrm{O}_{7}\right)_{3} .28 \mathrm{H}_{2} \mathrm{O}$ has a powder diffraction pattern plotted in (Figure 1) $\mathrm{Cr}_{4}\left(\mathrm{P}_{2} \mathrm{O}_{7}\right)_{3} .28 \mathrm{H}_{2} \mathrm{O}$ crystallizes in the monoclinic $\mathrm{P} 2 / \mathrm{m}$ with the following unit-cell dimensions: $\mathrm{a}=16.169(1) \AA, \mathrm{b}=9.336(5) \AA, \mathrm{c}=9.446(4) \AA, \beta=124.796(5)^{\circ}$, and $\mathrm{Z}=4$ and $\mathrm{V}$ $=587.98(1) \AA^{3}$. The figures of merit are $M(20)=93.3$ and $F(20)=263.3(0.0025,31)$. The lattice parameters and the merit figures, $\mathrm{M}$ and $\mathrm{F}$, were calculated using the computer programs Dicvol and Treor $[12,13]$.

The powder diffraction data of $\mathrm{Cr}_{4}\left(\mathrm{P}_{2} \mathrm{O}_{7}\right)_{3} .28 \mathrm{H}_{2} \mathrm{O}$ is reported in Table 1, and chemical analysis in Table 2. 


\subsubsection{Crystallographic data of $\mathrm{Cr}_{4}\left(\mathrm{P}_{2} \mathrm{O}_{7}\right)_{3}$.}

The crystallographic data and the final atomic positions of the non-hydrogen atoms of the $\mathrm{Cr}_{4}\left(\mathrm{P}_{2} \mathrm{O}_{7}\right)_{3}$ [14] structure are given in Tables 3 and 4. A projection of the $\mathrm{Cr}_{4}\left(\mathrm{P}_{2} \mathrm{O}_{7}\right)_{3}$ atomic arrangement along the b-axis is illustrated in Figure 2. It shows that all the atomic arrangement components are located around axis 2 to form networks delimiting large channels parallel to direction $\mathrm{b}$. Each anion is connected to its neighbor by a strong hydrogen bond, giving rise to infinite ribbons extending along with the $\mathrm{b}$ axis Figure 3 .

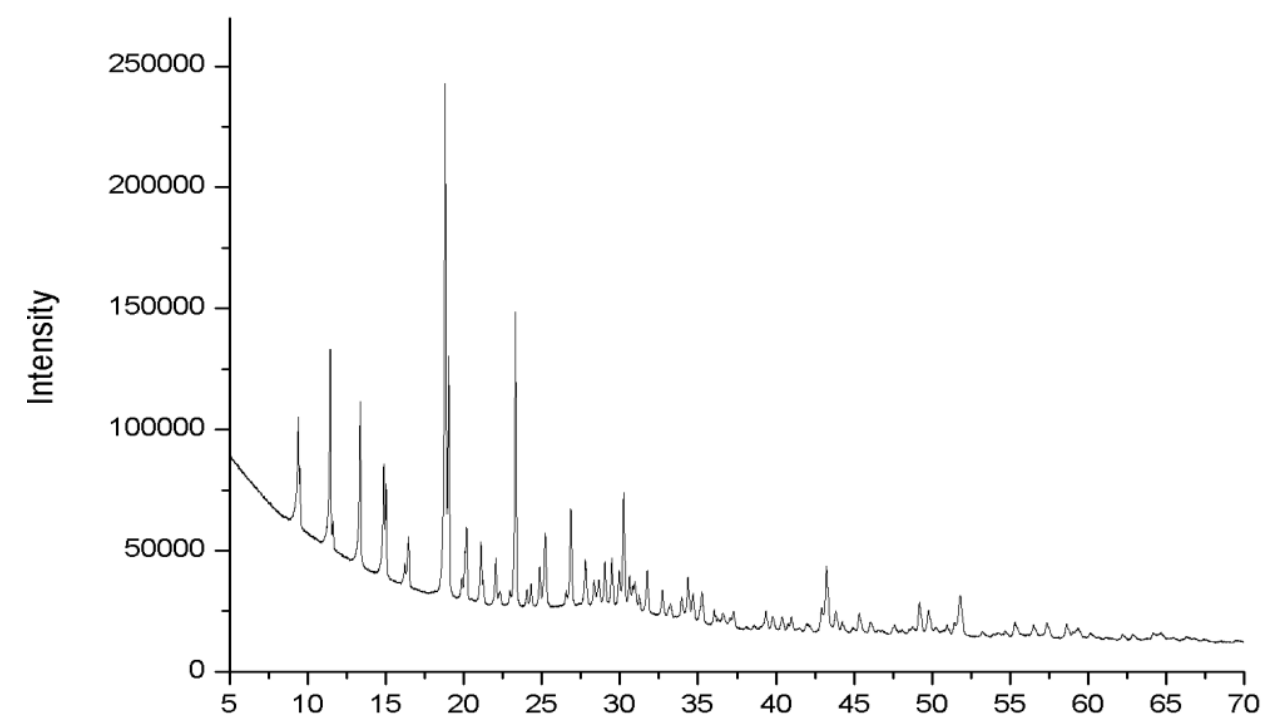

Figure 1. X-ray powder diffractogram of the phosphate $\mathrm{Cr}_{4}\left(\mathrm{P}_{2} \mathrm{O}_{7}\right)_{3} .28 \mathrm{H}_{2} \mathrm{O}$.

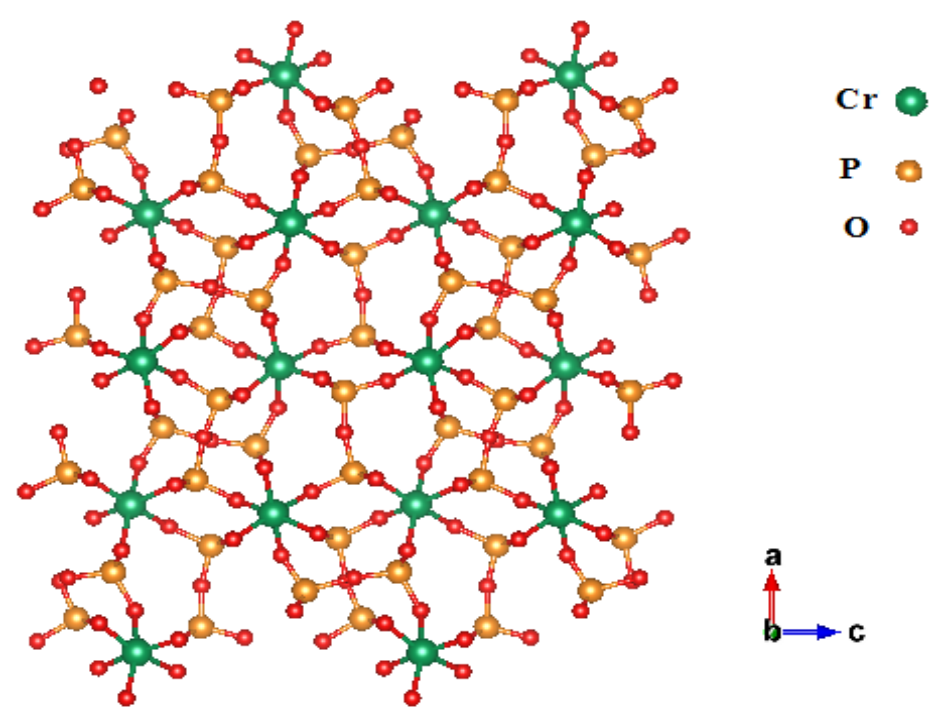

Figure 2. Projection along the $\mathrm{b}$ axis of the atomic arrangement in $\mathrm{Cr}_{4}\left(\mathrm{P}_{2} \mathrm{O}_{7}\right)_{3}$.

Table 1. Powder diffraction data of $\mathrm{Cr}_{4}\left(\mathrm{P}_{2} \mathrm{O}_{7}\right)_{3} \cdot 28 \mathrm{H}_{2} \mathrm{O}$.

\begin{tabular}{|c|c|c|c|c|c|c|c|c|c|c|c|c|c|}
\hline $2 \theta_{\mathrm{obs}}{ }^{\circ}$ & $d_{\mathrm{obs}} \AA$ & $I_{\text {obs }}$ & $h k l$ & $d_{\mathrm{cal}} \AA$ & $2 \theta_{\mathrm{cal}^{\circ}}$ & $\Delta 2 \theta^{\circ}$ & $2 \theta_{\mathrm{obs}}^{\circ}$ & $d_{\text {obs }} \AA$ & $I_{\mathrm{obs}}$ & $h k l$ & $d_{\mathrm{cal}} \boldsymbol{A}$ & $2 \theta_{\mathrm{cal}^{\circ}}$ & $\Delta \mathbf{2} \theta^{\circ}$ \\
\hline 9.49 & 9.309 & 44 & $\begin{array}{llll}0 & 1 & 0 \\
\end{array}$ & 9.308 & 9.49 & 0.00 & 27.78 & 3.208 & 22 & $32-2$ & 3.209 & 27.78 & 0.00 \\
\hline 11.42 & 7.736 & 56 & $\begin{array}{lll}0 & 0 & 1\end{array}$ & 7.738 & 11.43 & 0.01 & 28.65 & 3.112 & 20 & 030 & 3.109 & 28.69 & -0.04 \\
\hline 13.35 & 6.625 & 47 & $\begin{array}{lll}1 & 1 & -1\end{array}$ & 6.626 & 13.35 & 0.00 & 29.95 & 2.981 & 32 & 0222 & 2.980 & 29.97 & -0.01 \\
\hline 14.86 & 5.955 & 36 & $\begin{array}{lll}0 & 0 & 1 \\
\end{array}$ & 5.955 & 14.86 & 0.00 & 30.61 & 2.918 & 15 & $21-3$ & 2.918 & 30.61 & 0.00 \\
\hline 16.20 & 5.464 & 24 & $\begin{array}{lll}1 & 0 & 1 \\
\end{array}$ & 5.464 & 16.21 & 0,01 & 30.96 & 2.885 & 18 & $\begin{array}{lll}0 & 3 & 1\end{array}$ & 2.886 & 30.96 & 0.01 \\
\hline 18.80 & 4.716 & 100 & $\begin{array}{lll}1 & 1 & 1\end{array}$ & 4.715 & 18.81 & 0,01 & 31.24 & 2.861 & 12 & $10-3$ & 2.860 & 31.24 & -0.01 \\
\hline 19.86 & 4.466 & 26 & $\begin{array}{lll} & 0 & -2 \\
\end{array}$ & 4.467 & 19.86 & 0.00 & 32.71 & 2.736 & 14 & $11-3$ & 2.735 & 32.72 & -0.01 \\
\hline 21.09 & 4.209 & 23 & $2 \quad 1-2$ & 4.208 & 21.09 & 0.00 & 33.94 & 2.639 & 11 & $52-2$ & 2.639 & 33.94 & 0.00 \\
\hline 21.23 & 4.180 & 20 & $\begin{array}{lll}1 & 2 & -1\end{array}$ & 4.179 & 21.24 & 0.01 & 34.68 & 2.584 & 18 & $\begin{array}{llll}0 & 0 & 3\end{array}$ & 2.584 & 34.69 & 0.00 \\
\hline 23.30 & 3.814 & 62 & $\begin{array}{lll}22 & 0\end{array}$ & 3.814 & 23.30 & 0.00 & 36.04 & 2.490 & 9 & $\begin{array}{llll}0 & 1 & 3\end{array}$ & 2.490 & 36.04 & 0.00 \\
\hline
\end{tabular}




\begin{tabular}{|c|c|c|c|c|c|c|c|c|c|c|c|c|c|}
\hline $2 \theta_{\mathrm{obs}}{ }^{\circ}$ & $d_{\text {obs }} \AA$ & $I_{\text {obs }}$ & $h k l$ & $d_{\text {cal }} \stackrel{\circ}{A}$ & $2 \theta \mathrm{cal}^{\circ}$ & $\Delta 2 \theta^{\circ}$ & $2 \theta_{\mathrm{obs}}{ }^{\circ}$ & $d_{\text {obs }} \AA$ & $I_{\text {obs }}$ & h $k l$ & $d_{\text {cal }} \stackrel{\circ}{A}$ & $2 \theta_{\mathrm{cal}^{\circ}}$ & $\Delta 2 \theta^{\circ}$ \\
\hline 24.04 & 3.699 & 15 & $\begin{array}{lll}2 & 1 & 1\end{array}$ & 3.698 & 24.04 & 0.00 & 39.34 & 2.288 & 7 & $\begin{array}{lll}4 & 1 & -4\end{array}$ & 2.287 & 39.35 & -0.01 \\
\hline 24.30 & 3.659 & 18 & $\begin{array}{lll}4 & 1 & -1 \\
\end{array}$ & 3.659 & 24.31 & 0.01 & 42.92 & 2.105 & 11 & $\begin{array}{lll}1 & 3 & -3 \\
\end{array}$ & 2.106 & 42.91 & 0.01 \\
\hline 24.86 & 3.578 & 26 & $\begin{array}{lll}0 & 1 & 2\end{array}$ & 3.578 & 24.87 & -0.01 & 43.34 & 2.085 & 19 & $\begin{array}{lll}3 & 2 & -4 \\
\end{array}$ & 2.084 & 43.37 & -0.03 \\
\hline 25.24 & 3.528 & 6 & $\begin{array}{lll}3 & 2 & -1\end{array}$ & 3.525 & 25.22 & -0.02 & 49.77 & 1.830 & 13 & $15-1$ & 1.831 & 49.76 & -0.01 \\
\hline 26.86 & 3.317 & 9 & $22-2$ & 3.316 & 26.86 & 0.00 & 51.82 & 1.763 & 14 & $35-1$ & 1.763 & 51.80 & 0.02 \\
\hline
\end{tabular}

\subsection{Chemical analyzes.}

The chemical analysis was done by atomic absorption using a VARIAN AA-475 spectrometer. The results of the chemical analysis are consistent with the formula $\mathrm{Cr}_{4}\left(\mathrm{P}_{2} \mathrm{O}_{7}\right)_{3} .28 \mathrm{H}_{2} \mathrm{O}$. The table below summarizes the results of the chemical analysis of $\mathrm{Cr}_{4}\left(\mathrm{P}_{2} \mathrm{O}_{7}\right)_{3} .28 \mathrm{H}_{2} \mathrm{O}$.

Table 2. Results of the chemical analyzes

\begin{tabular}{c|c|c|c|c|c}
\multicolumn{2}{c|}{$\mathbf{~ r ~}$} & \multicolumn{2}{c}{$\mathbf{P}$} & \multicolumn{2}{c}{$\mathbf{H}_{2} \mathbf{O}$} \\
\hline Theoretical & Experimental & Theoretical & Experimental & Theoretical & Experimental \\
\hline 4 & 3.99 & 6 & 6.01 & 28 & 27.8
\end{tabular}

$\mathrm{Cr}_{4}\left(\mathrm{P}_{2} \mathrm{O}_{7}\right)_{3} .28 \mathrm{H}_{2} \mathrm{O}$ is stable under ambient conditions of temperature and pressure. We monitored IR stability, X-ray diffraction, and thermogravimetric stability for about six months, and no changes or changes in the degree of hydration were observed over time.

Table 3. Crystal structure data for $\mathrm{Cr}_{4}\left(\mathrm{P}_{2} \mathrm{O}_{7}\right)_{3}$.

\begin{tabular}{|c|c|}
\hline Compound & 2 \\
\hline Empirical Formula & $\mathrm{Cr}_{4}\left(\mathrm{P}_{2} \mathrm{O}_{7}\right)_{3}$ \\
\hline molar mass & $729.8144 \mathrm{~g} / \mathrm{mol}$ \\
\hline Crystal System / Space Group & orthorhombic / P bnm \\
\hline $\mathrm{a} / \AA$ & $9.3850(1) \AA$ \\
\hline $\mathrm{b} / \AA$ & $21.0000(5) \AA$ \\
\hline $\mathrm{c} / \AA$ & $7.2600(2) \AA$ \\
\hline$\alpha /{ }^{\circ}$ & $90^{\circ}$ \\
\hline$\beta /^{\circ}$ & $90^{\circ}$ \\
\hline$\gamma /{ }^{\circ}$ & $90^{\circ}$ \\
\hline $\mathrm{V} / \AA^{3}$ & $1430.07(6) \AA^{3}$ \\
\hline $\mathrm{Z}$ & 4 \\
\hline$D_{\text {calc }}\left(\mathrm{g} / \mathrm{cm}^{3}\right)$ & $3.39 \mathrm{~g} / \mathrm{cm}^{3}$ \\
\hline$\mu\left(\mathrm{mm}^{-1}\right)$ & 7.362 \\
\hline Crystal size $(\mathrm{mm})$ & $0.18 \times 0.18 \times 0.43 \mathrm{~mm}^{3}$ \\
\hline Color / Shape & Colorless / Prism \\
\hline Temp (K) & $297(2) \mathrm{K}$ \\
\hline Theta range for collection & $3.59^{\circ} / 31.49^{\circ}$ \\
\hline Reflections collected & 3278 \\
\hline Independent reflections & 2895 \\
\hline Data/restraints/parameters & $2448 / 0 / 147$ \\
\hline Goodness of fit on $\mathrm{F}^{2}$ & 1.113 \\
\hline Final $R$ indices $[\mathrm{I}>2 \sigma(\mathrm{I})]$ & $\mathrm{R}_{1}=0.0325, \mathrm{wR}_{2}=0.1166$ \\
\hline $\mathrm{R}$ indices (all data) & $\mathrm{R}_{1}=0.0329, \mathrm{wR}_{2}=0.1138$ \\
\hline Largest difference peak / hole $\left(\mathrm{A}^{-3}\right)$ & $0.78 /-1.40$ \\
\hline
\end{tabular}

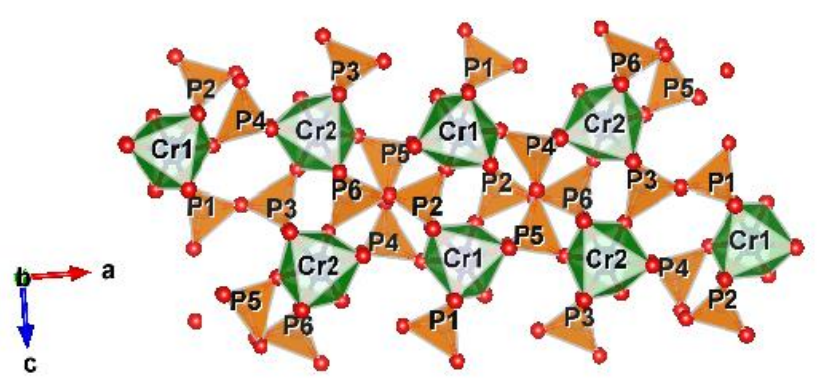

Figure 3. Projection along the $\mathrm{b}$ axis of the atomic arrangement in $\mathrm{Cr}_{4}\left(\mathrm{P}_{2} \mathrm{O}_{7}\right)_{3}$. 
Table 4. Final atomic coordinates and $U$ equivalent temperature factors for $\mathrm{Cr}_{4}\left(\mathrm{P}_{2} \mathrm{O}_{7}\right)_{3}$.

\begin{tabular}{l|c|c|c|c} 
Atoms & $\mathbf{X}$ & $\mathbf{Y}$ & $\mathbf{Z}$ & Site \\
\hline Cr1 & 0.00364 & 0.05362 & 0.26062 & $8 \mathrm{~d}$ \\
\hline Cr2 & 0.24355 & 0.05333 & 0.77933 & $8 \mathrm{~d}$ \\
\hline P3 & 0.04777 & 0.75000 & 0.03233 & $4 \mathrm{c}$ \\
\hline P4 & 0.06126 & 0.75000 & 0.47111 & $4 \mathrm{c}$ \\
\hline P5 & 0.10934 & 0.25000 & 0.66728 & $4 \mathrm{c}$ \\
\hline P6 & 0.14175 & 0.25000 & 0.34272 & $4 \mathrm{c}$ \\
\hline P7 & 0.18918 & 0.75000 & 0.00152 & $4 \mathrm{c}$ \\
\hline P8 & 0.19933 & 0.75000 & 0.55343 & $4 \mathrm{c}$ \\
\hline O10 & 0.02730 & 0.58254 & 0.10192 & $8 \mathrm{~d}$ \\
\hline O11 & 0.05296 & 0.58173 & 0.39299 & $8 \mathrm{~d}$ \\
\hline O12 & 0.07399 & 0.08123 & 0.69721 & $8 \mathrm{~d}$ \\
\hline O13 & 0.17693 & 0.08248 & 0.30915 & $8 \mathrm{~d}$ \\
\hline O14 & 0.19961 & 0.58117 & 0.92262 & $8 \mathrm{~d}$ \\
\hline O16 & 0.21379 & 0.58082 & 0.62587 & $8 \mathrm{~d}$ \\
\hline O17 & 0.02276 & 0.75000 & 0.60554 & $4 \mathrm{c}$ \\
\hline O18 & 0.03135 & 0.75000 & 0.87689 & $4 \mathrm{c}$ \\
\hline O19 & 0.07781 & 0.25000 & 0.26730 & $4 \mathrm{c}$ \\
\hline O20 & 0.11961 & 0.75000 & 0.04732 & $4 \mathrm{c}$ \\
\hline O21 & 0.12746 & 0.25000 & 0.50629 & $4 \mathrm{c}$ \\
\hline O22 & 0.12890 & 0.75000 & 0.52812 & $4 \mathrm{c}$ \\
\hline O23 & 0.17087 & 0.25000 & 0.74974 & $4 \mathrm{c}$ \\
\hline
\end{tabular}

\subsection{Vibrational studies}

The pyrophosphate group has a quasi-eclipsed conformation, making it possible to consider the $\mathrm{C}_{2 v}$ group as a molecular group of symmetry. The 21 fundamental vibrations of the $\mathrm{P}_{2} \mathrm{O}_{7}$ groups are thus distributed as follows [5]:

$$
\Gamma_{\mathrm{vib}}\left(\mathrm{C}_{2 \mathrm{v}}\right)=7 \mathrm{~A}_{1} \oplus 4 \mathrm{~A}_{2} \oplus 4 \mathrm{~B}_{1} \oplus 6 \mathrm{~B}_{2}
$$

Normal coordinate analysis performed a distribution of the 21 normal modes of internal vibration.

$$
\begin{array}{cc}
\Gamma_{1}=2 \mathrm{~A}_{1} \oplus \mathrm{A}_{2} \oplus \mathrm{B}_{1} \oplus 2 \mathrm{~B}_{2} & \text { Valence vibration of } \mathrm{PO}_{3} \text { groups } \\
\Gamma_{2}=\mathrm{A}_{1} \oplus \mathrm{B}_{2} & \text { POP bridge stretching vibration } \\
\Gamma_{3}=3 \mathrm{~A}_{1} \oplus 3 \mathrm{~A}_{2} \oplus 3 \mathrm{~B}_{1} \oplus+3 \mathrm{~B}_{2} & \text { Deformation vibration of } \mathrm{PO}_{3} \text { groups } \\
\Gamma_{4}=\mathrm{A}_{1} & \text { Vibration deformation of the POP bridge }
\end{array}
$$

Table 5 gives the correlation diagram for the $\mathrm{P}_{2} \mathrm{O}_{7}^{4-}$ ion. The enumeration of normal modes of vibration in the crystal realized using the method of the site [15] shows that the 84 vibrations of the ion $\mathrm{P}_{2} \mathrm{O}_{7}{ }^{4-}$ are distributed as follows:

$$
\Gamma_{\mathrm{vib}}=21 \mathrm{Ag}_{\mathrm{g}} \oplus 21 \mathrm{~B}_{\mathrm{g}} \oplus 21 \mathrm{~A}_{\mathrm{u}} \oplus 21 \mathrm{~B}_{\mathrm{u}}
$$

Using the same method, the counting of the external vibrations in the crystal shows that the rotation vibrations of the group $\mathrm{P}_{2} \mathrm{O}_{7}{ }^{4-}$ are distributed as follows:

$$
\Gamma_{\mathrm{R}}=3 \mathrm{~A}_{\mathrm{g}} \oplus 3 \mathrm{~B}_{\mathrm{g}} \oplus 3 \mathrm{~A}_{\mathrm{u}} \oplus 3 \mathrm{~B}_{\mathrm{u}}
$$

Concerning the translation movements of the ions $\mathrm{P}_{2} \mathrm{O}_{7}^{4-}, \mathrm{A}^{2+}, \mathrm{M}^{2+}$, they are distributed as follows: 


$$
\begin{gathered}
\Gamma_{\mathrm{T}}=9 \mathrm{Ag}_{\mathrm{g}} \oplus 9 \mathrm{~B}_{\mathrm{g}} \oplus 9 \mathrm{~A}_{\mathrm{u}} \oplus 9 \mathrm{~B}_{\mathrm{u}} \\
\text { and } \Gamma_{\mathrm{ac}}=\mathrm{Au}_{\mathrm{u}} \oplus 2 \mathrm{~B}_{\mathrm{u}}
\end{gathered}
$$

The internal vibration distribution in terms of group vibration is as follows [16-19]:

$$
\begin{aligned}
& \Gamma_{\text {valence }}\left(\mathrm{PO}_{3}\right)=6 \mathrm{Ag}_{\mathrm{g}} \oplus 6 \mathrm{Bg}_{\mathrm{g}} \oplus 6 \mathrm{Au} \oplus 6 \mathrm{~B}_{\mathrm{u}} \\
& \Gamma_{\text {valence }}(\mathrm{POP})=2 \mathrm{Ag}_{\mathrm{g}} \oplus 2 \mathrm{~B}_{\mathrm{g}} \oplus 2 \mathrm{~A}_{\mathrm{u}} \oplus 2 \mathrm{~B}_{\mathrm{u}} \\
& \Gamma_{\text {deformation }}\left(\mathrm{PO}_{3}\right)=12 \mathrm{Ag} \oplus 12 \mathrm{Bg} \oplus 12 \mathrm{Au} \oplus 12 \mathrm{Bu}_{\mathrm{u}}
\end{aligned}
$$

Table 5. Internal and External Vibration Modes of the $\mathrm{P}_{2} \mathrm{O}_{7}$ Group.

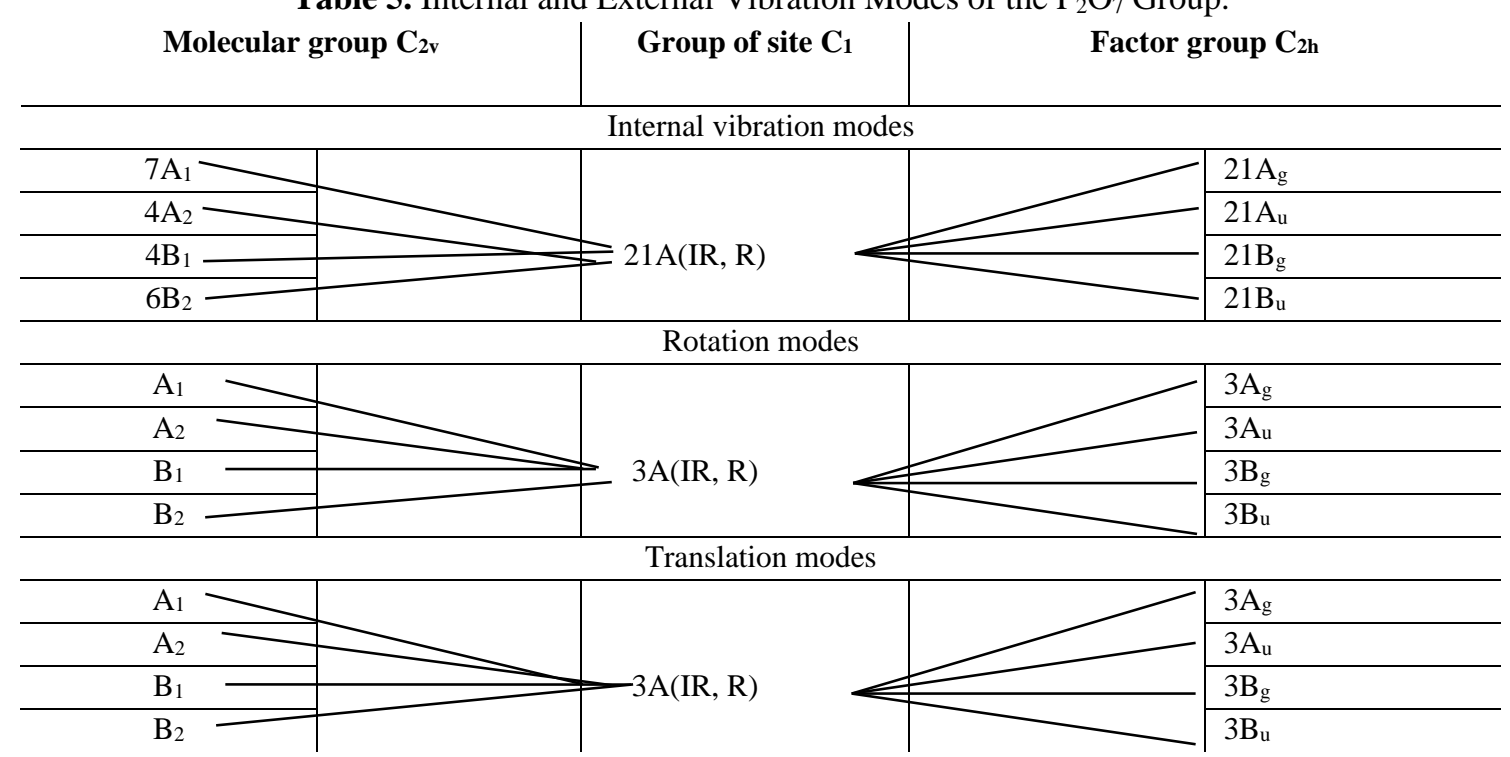

By grouping the different modes of vibration, the total representation of crystals $\mathrm{Cr}_{4}\left(\mathrm{P}_{2} \mathrm{O}_{7}\right)_{3} .28 \mathrm{H}_{2} \mathrm{O}$ is:

$$
\text { Гtotal }=27 \mathrm{Ag}_{\mathrm{g}} \oplus 27 \mathrm{~B}_{\mathrm{g}} \oplus 27 \mathrm{Au}_{\mathrm{u}} \oplus 27 \mathrm{~B}_{\mathrm{u}}
$$

The IR absorption spectra of $\mathrm{Cr}_{4}\left(\mathrm{P}_{2} \mathrm{O}_{7}\right)_{3} .28 \mathrm{H}_{2} \mathrm{O}$ and $\mathrm{Cr}_{4}\left(\mathrm{P}_{2} \mathrm{O}_{7}\right)_{3}$ are reported in Figure 4. In the 4000-1600 $\mathrm{cm}^{-1}$ range, the spectra show bands that are allocated to valence and deformation vibrations of water molecules. The valence vibration bands of water molecules $(\mathrm{vOH})$ are between 4000 and $3000 \mathrm{~cm}^{-1}$. The water molecules' deformation vibration bands $(\delta \mathrm{HOH})$ exist between 1700 and $1600 \mathrm{~cm}^{-1}$ [20-22].

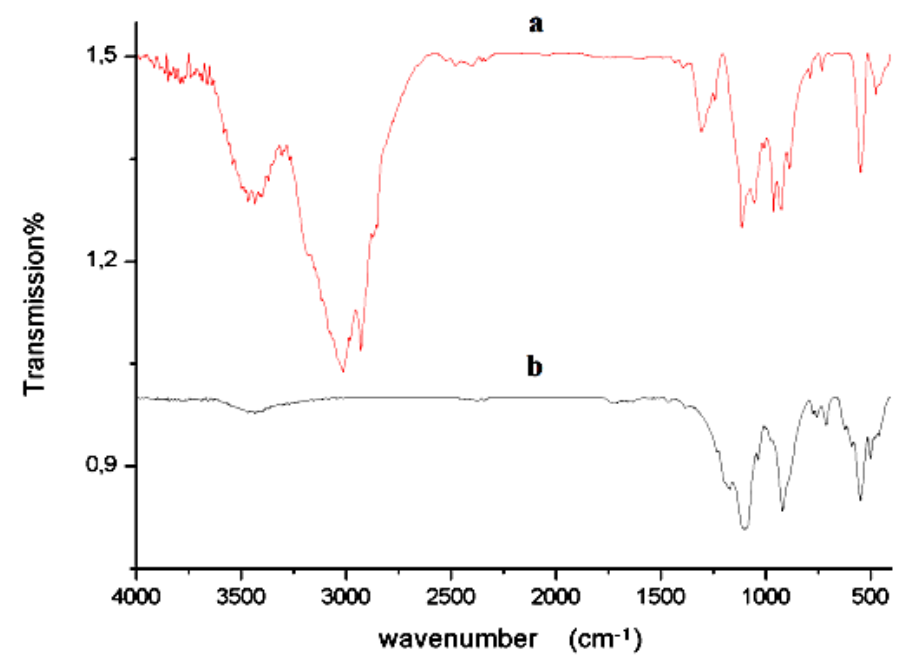

Figure 4. FT-IR spectra of (a) for $\mathrm{Cr}_{4}\left(\mathrm{P}_{2} \mathrm{O}_{7}\right)_{3} .28 \mathrm{H}_{2} \mathrm{O}$; (b) for $\mathrm{Cr}_{4}\left(\mathrm{P}_{2} \mathrm{O}_{7}\right)_{3}$. 
Between 1340 and $660 \mathrm{~cm}^{-1}$, the IR absorption spectra of $\mathrm{Cr}_{4}\left(\mathrm{P}_{2} \mathrm{O}_{7}\right)_{3} .28 \mathrm{H}_{2} \mathrm{O}$ and $\mathrm{Cr}_{4}\left(\mathrm{P}_{2} \mathrm{O}_{7}\right)_{3}$ (Figure 4) show valence vibration bands characteristic of phosphates with $\mathrm{P}_{2} \mathrm{O}_{7}{ }^{4-}$ anions.

The vibrations corresponding to the different valence and deformation bands are grouped in Table 6.

Table 6. Frequencies $\left(\mathrm{cm}^{-1}\right)$ of IR absorption bands for $\mathrm{Cr}_{4}\left(\mathrm{P}_{2} \mathrm{O}_{7}\right)_{3} \cdot 28 \mathrm{H}_{2} \mathrm{O}$.

\begin{tabular}{c|c|c}
\multicolumn{2}{c|}{ Frequencies $\mathbf{v}\left(\mathbf{c m}^{-\mathbf{1}}\right)$} & \multirow{2}{*}{ Movements } \\
\cline { 1 - 2 } $\mathbf{C r}_{\mathbf{4}}\left(\mathbf{P}_{\mathbf{2}} \mathbf{O}_{7}\right)_{\mathbf{3} .28 \mathbf{H}_{\mathbf{2}} \mathbf{O}}$ & $\mathbf{C r}_{\mathbf{4}}\left(\mathbf{P}_{\mathbf{2}} \mathbf{O}_{7}\right)_{\mathbf{3}}$ & $\mathrm{V} \mathrm{O}-\mathrm{H}$ \\
\hline 3427 & - & $\mathrm{V}_{\delta} \mathrm{H}-\mathrm{O}-\mathrm{H}$ \\
\hline 2360 & - & \multirow{2}{*}{$\mathrm{V}_{\text {as }} \mathrm{PO}_{3}$} \\
\hline 1670 & 1270 & $\mathrm{~V}_{\mathrm{s}} \mathrm{PO}_{3}$ \\
\hline 1116 & 1112 & \multirow{2}{*}{$\mathrm{V}_{\text {as }} \mathrm{POP}$} \\
\hline 996 & 980 & \\
\hline 920 & 915 & $\delta_{\text {as }} \mathrm{PO}_{3}$ \\
\hline 735 & 740 & $\delta_{\mathrm{s}} \mathrm{PO}_{3}$ \\
\hline 485 & 680 & \\
\hline
\end{tabular}

\subsection{Thermal behavior.}

Figure 5 shows the thermogram of TGA-DTA coupled with thermal dehydration at atmospheric pressure of $\mathrm{Cr}_{4}\left(\mathrm{P}_{2} \mathrm{O}_{7}\right)_{3} .28 \mathrm{H}_{2} \mathrm{O}$ by linear temperature rise with heating rate $10^{\circ} \mathrm{C} / \mathrm{min}$. The analysis is carried out shows that the temperature increases linearly between 25 and $600^{\circ} \mathrm{C}$.

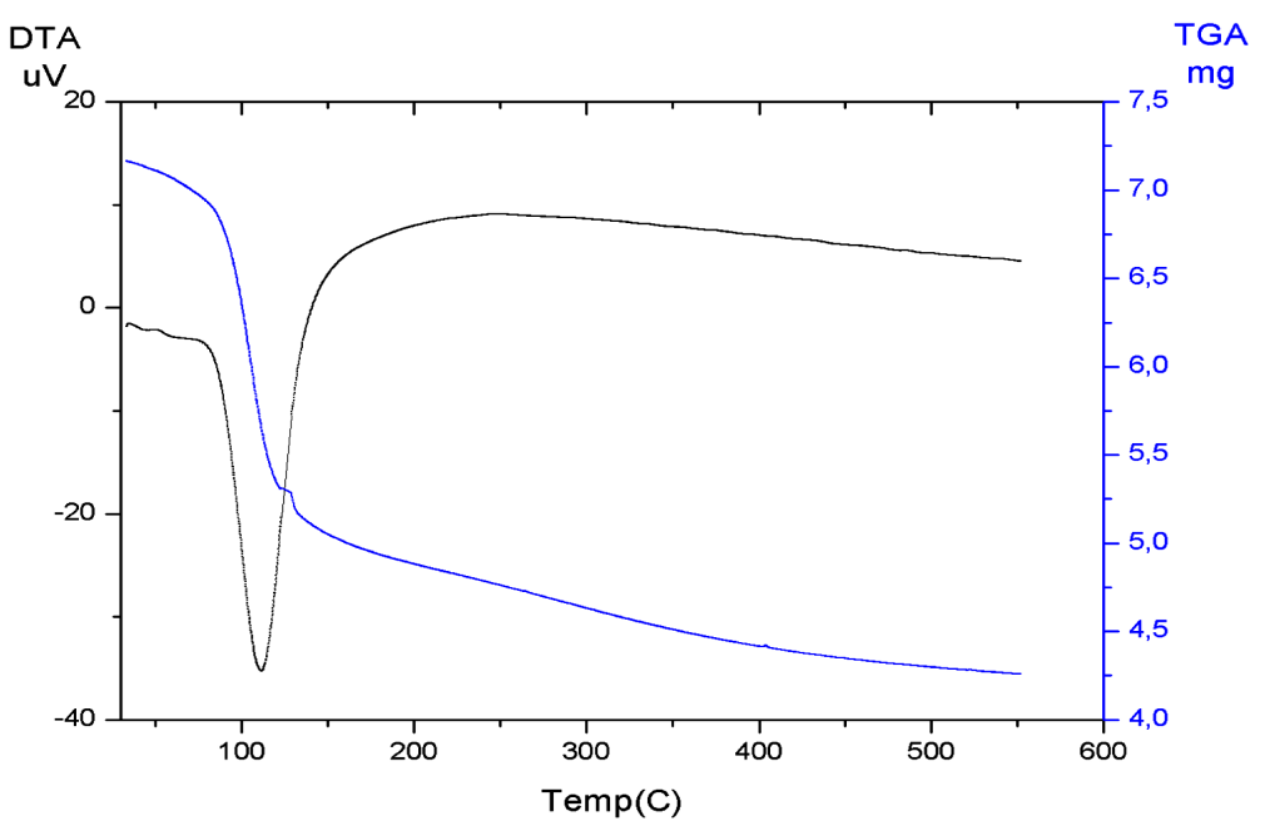

Figure 5. TGA-DTA coupled with thermal dehydration at atmospheric pressure of $\mathrm{Cr}_{4}\left(\mathrm{P}_{2} \mathrm{O}_{7}\right)_{3} .28 \mathrm{H}_{2} \mathrm{O}$ with heating rate $10^{\circ} \mathrm{C} / \mathrm{min}$.

The TGA thermograms realized at different heating rates all have the same speed and two mass loss stages corresponding to twenty-eight water molecules perform unit. For the heating rate of $10^{\circ} \mathrm{C} / \mathrm{min}$, the ATG curve has two stages of loss of mass: 
- The first step between $40^{\circ} \mathrm{C}$ and $120^{\circ} \mathrm{C}$ corresponds to the rapid elimination of water with a maximum dehydration rate at $110{ }^{\circ} \mathrm{C}$ with a very intense peak. At $120^{\circ} \mathrm{C}$, the weight loss is $28 \%$ of the hydrate's molar mass and corresponds to the elimination of $18 \mathrm{H}_{2} \mathrm{O}$.

- The second step between 120 and $500^{\circ} \mathrm{C}$ corresponds to a mass loss of $12 \%$ of the hydrate's molar mass and results in a continuous removal of $10 \mathrm{H}_{2} \mathrm{O}$, with a maximum dewatering rate at $170^{\circ} \mathrm{C}$.

\section{Conclusions}

The new chromium diphosphate hydrate has been prepared by the method of ion exchange resin. The title compound was characterized by crystallography using the computer programs Dicvol and Treor, and we found the same unit-cell parameters and good factors of merit. The unit-cell parameters are the following: $a=16.169(1) \AA, b=9.336(5) \AA, c=$ 9.446(4) $\AA, \beta=124.796(5)^{\circ}$, and $Z=4$. The thermal behavior of chromium diphosphate hydrate has been studied by X-ray diffraction, infrared spectroscopy, and thermal analyses TGA-DTA. After partial dehydration, the new chromium diphosphate hydrate leads to an amorphous phase by X-ray diffraction and IR spectroscopy. The final product of the total thermal dehydration of $\mathrm{Cr}_{4}\left(\mathrm{P}_{2} \mathrm{O}_{7}\right)_{3} .28 \mathrm{H}_{2} \mathrm{O}$ under atmospheric pressure is its corresponding anhydrous diphosphate of chromium. The structure of the diphosphate of chromium was reinvestigated by X-ray diffraction and IR spectroscopy. The vibrational spectra of chromium diphosphate hydrate and its corresponding anhydrous have been examined and interpreted in the domain of the stretching vibrations of the $\mathrm{P}_{2} \mathrm{O}_{7}^{4-}$ anion.

\section{Funding}

This research received no external funding.

\section{Acknowledgments}

The authors are indebted to Dr. Aziz Kheireddine for the X-ray measurements to solve the crystal structure.

\section{Conflicts of Interest}

The authors declare no conflict of interest.

\section{References}

1. Zaldo, C.; Martín, M.J.; Solé, R.; Aguiló, M.; Díaz, F.; Roura, P.; López de Miguel, M. Optical spectroscopy of Ho3+ and Tm3+ ions in KTiOPO4 single crystals. Opt. Mater. 1998, 10, 29-37, https://doi.org/10.1016/S0925-3467(97)00053-0.

2. Muthuselvi, C.; Rathika, N.; Selvalaksh, K. Vibrational, Optical and Antimicrobial Activity Studies on Diglycine Perchlorate Single Crystal. Journal of Applied Sciences 2019, 19, 848-856, https://doi.org/10.3923/jas.2019.848.856.

3. Allouche, F.; Selmi, W.; Zid, M.F.; Benlecheb, T. Theoretical and experimental study of new hybrid compound rich in hydrogen bonding: 2-carboxyanilinium hypophosphite. J. Mol. Struct. 2019, 1179, 756763, https://doi.org/10.1016/j.molstruc.2018.11.069.

4. Jouini, A.; Gâcon, J.C.; Ferid, M.; Trabelsi-Ayadi, M. Luminescence and scintillation properties of praseodymium poly and diphosphates. Opt. Mater. 2003, 24, 175-180, https://doi.org/10.1016/S09253467(03)00122-8. 
5. Marouani, H.; Oubouaza, R.; Zerraf, S.; Ouasri, A.; Tridane, M.; Belaaouad, S. Chemical preparations, crystal data for monophosphates and condensed Phosphates associated to manganese and IR studies of their anions. International Journal of Emerging Trends in Engineering Research, 2020, 8, 4784-4798, https://doi.org/10.30534/ijeter/2020/116882020.

6. Charaf, A.; Fahim, I.; Tace, E.M.; Tridane, M.; Radid, M.; Belaaouad, S. Physico-chemical studies of $\mathrm{CuNa}_{3} \mathrm{P}_{3} \mathrm{O}_{10} .12 \mathrm{H}_{2} \mathrm{O}$, crystallographic characterization of $\mathrm{CuNa}_{3} \mathrm{P}_{3} \mathrm{O}_{10}$ and quantum chemical calculations of the $\mathrm{P}_{3} \mathrm{O}_{10}{ }^{5-}$ ion. Phosphorus Research Bulletin 2010, 24, 83-90, https://doi.org/10.3363/prb.24.83.

7. Cherif, O.; Agrebi, A.; Alves, S.; Baleizão, C.; Farinha, J.P.; Allouche, F. Synthesis and fluorescence properties of aminocyanopyrrole and aminocyanothiophene esthers for biomedical and bioimaging applications. J. Mol. Struct. 2020, 1209, 127974, https://doi.org/10.1016/j.molstruc.2020.127974.

8. Zerraf, S.; Belhabra, M.; Tridane, M.; Belaaouad, S. Chemical preparations, crystal data for monophosphates and condensed phosphates associated to barium and IR studies of their anions. International Journal of Advanced Research (IJAR) 2019, 2320-5407, http://dx.doi.org/10.21474/IJAR01/8432.

9. Oubouaza, R.; Marouani, H.; Zerraf, S.; Belhabra, M.; Ouasri, A.;Tridane, M.; Belaaouad,S. Chemical preparations, crystal data for monophosphates and condensed phosphates associated to strontium and IR studies of their anions. International Journal of Emerging Trends in Engineering Research, 2020, 8, 65876598, http://dx.doi.org/10.30534/ijeter/2020/265892020.

10. Tridane, M.; Belaaouad, S.; Sbai, K. Chemical preparations and crystal data for eight new condensed phosphates. Solid State Sciences 2000, 2, 701-704, http://dx.doi.org/10.1016/S1293-2558(00)01081-5.

11. Zerraf, S.; Tridane, M.; Belaaouad, S. Crystal structure, vibrational and spectroscopic study of single crystal (C6H15N4O2) H2PO4. H2O. Moroccan Journal of Chemistry 2020, 8, 8-2, https://doi.org/10.48317/IMIST.PRSM/morjchem-v8i2.16988.

12. Louer, D.; Louer, M. Méthode d'essais et erreurs pour l'indexation automatique des diagrammes de poudre. J. Appl. Crystallogr. 1972, 5, 271-275, https://doi.org/10.1107/S0021889872009483.

13. Louer, D.; Vargas, R. Indexation automatique des diagrammes de poudre par dichotomies successives. $J$. Appl. Crystallogr. 1982, 15, 542-545, https://doi.org/10.1107/S0021889882012552.

14. Schlesinger, K.; Ziemer, B.; Hanke, W.; Ladwig, G. Über die Diphosphate M4(P2O7)3 mit M = V, Cr und die Elektronenspektren von Vanadium (III)- und Chrom(III)-Phosphaten. Z. Anorg. Allg. Chem. 1983, 500, 104-116, https://doi.org/10.1002/zaac.19835000514.

15. Belhabra, M.; Zerraf, S.; Kheireddine, A.; Altomare, A.; Tridane, M.; Ouasri, A.; Radid, M.; Belaaouad, S. Structural and vibrational study of diphenylhydrazine dihydrogenophosphate single crystal (C6H9N2)2H2P2O7 (DPHDP). Chemical Data Collections 2018, 13-14, 73-83, https://doi.org/10.1016/j.cdc.2018.01.002.

16. Zerraf, S.; Tridane, M.; Belaaouad, S. Data of infrared vibration spectroscopy of cyclotriphosphates. Data in Brief 2019, 25, 104075, https://doi.org/10.1016/j.dib.2019.104075.

17. Zerraf, S.; Belhabra, M.; Kheireddine, A.; Lamsatfi, R.; Tridane, M.; Moutaabbid, H.; Baptiste, B.; Moutaabbid, M.; Belaaouad, S. Reinvestigation of the crystal structure of barium cesium cyclotriphosphate dihydrate and vibrational study. Phosphorus, Sulfur, and Silicon and the Related Elements 2017, 192, 12861293, https://doi.org/10.1080/10426507.2017.1333507.

18. Marouani, H.; Tridane, M.; Majdi, El.; Zerraf, S.; Belhabra, M.; Belaaouad, S. Engineering Techniques applied for studies by Infrared vibration, crystallographic characterization and Thermal Behavior of two new cyclotriphosphates. International Journal of Emerging Trends in Engineering Research, 2020, 8, 239-246, https://doi.org/10.30534/ijeter/2020/30812020.

19. Makhloufy, S.E.L.; Tridane, M.; Marouani, H.; Zerraf, S.; Belhabra, M.; Cherqaoui, A.; Belaaouad, S. Chemical preparation, thermal behavior and infrared studies of the new cyclotriphosphate tetrahydrate of manganese and distrontium, MnSr2 (P3O9) 2.4 H2O. Mediterranean Journal of Chemistry 2019, 9, 280-289, http://dx.doi.org/10.13171/mjc941911141082sem.

20. Dewar, M.J.S.; Thiel, W. Ground states of molecules. 38. The MNDO method. Approximations and parameters. J. Am. Chem. Soc. 1977, 99, 4899-4907, https://doi.org/10.1021/ja00457a004.

21. Atibi, A.; El Kababi, K.; Belhabra, M.; Zerraf, S.; Tridane, M.; Belaaouad, S. Chemical preparation, crystal structure and vibrational study of a new dihydrogenotriphosphate trihydrate of 4-aminobenzoic acid fertilizer type NP. J. Coord. Chem. 2018, 71, 3510-3520, https://doi.org/10.1080/00958972.2018.1528579.

22. Majdi, El.; Zerraf, S. ; Marouani, H.; El Makhloufy, S.; Belhabra, M.; Ouasri, A.; Naimi, Y.; Belaaouad, S. Structural and vibrational study of titanium Monophosphates Na0. 5M0. 25Ti2 (PO4) 3 (M= Mn, Ni). Mediterranean Journal of Chemistry 2019, 9, 355-362, https://doi.org/10.13171/mjc01911281083emm. 